\title{
Development of Physics Learning Model Based of Islamic Boarding School's Learning Model to Improve Students' Problem Solving Skill
}

\author{
F Mudhofir ${ }^{1}$, S Suharto ${ }^{2}$, Sulhadi $^{3}$ \\ ${ }^{1,2,3}$ Graduate School, Universitas Negeri Semarang, Indonesia \\ ${ }^{1}$ MAS Tahfidz Yanbu'ul Qur'an Kab. Kudus, Central Java, Indonesia \\ ${ }^{1}$ Corresponding email: faizmudhofir@icloud.com
}

\begin{abstract}
Islamic boarding school (pondok pesantren) is an educational institution that has special characteristics. Developing a model based on boarding school of Tahfidz Yanbu'ul Qur'an Kawan Kudus is applied in physics learning. Learning model includes tahfidz learning, foreign language habitation, and classical islamic text book review. Model development resulted in the addition to independent activities before conducting group discussion activities. Students are personally facing the teacher to address group issues or interim results from group discussions. This is to hone the ability of students in getting used to being scientific. The results showed: (1) learning model developed was valid according to experts with an average value of 87.83 ; (2) a model developed was able to effectively improve the problem solving skills of students in medium category.
\end{abstract}

Key words: physics learning model, Islamic boarding school, learning model, problem-solving skill

\section{Introduction}

Interesting phenomenon is growing in the modern era in the world of education in Indonesia. There are three educational institutions that exist: schools, madrasah (islamic school), and boarding school (Anwar, 2008). Pesantren is one of the oldest Islamic educational institutions in Indonesia (Shafwan, 2014). In the beginning, boarding school is synonymous with religious science because it is only opened religious education such as madrasah diniyah and classical islamic text book review. As the times went by along with the demands from the state to modernize lessons, currently many boarding schools also open formal schools start from the lowest level of primary school to the higher levels. Many Islamic boarding school (pesantren) make changes both structurally and culturally (Rahardjo, 2006). A variety of science, language, and social lessons are taught in the school according to the existing curriculum.

Physics is one of the subjects taught in high school. The development of science and technology in the $21^{\text {st }}$ century requires students to compete globally. Therefore, it is needed a way of learning that can prepare students to be able to develop their potential optimally. The implementation of $21^{\text {st }}$ century skills requires the development of academic subjects through knowledge and understanding. Students must be able to think critically and communicate effectively (Alismail, 2015). The $21^{\text {st }}$ Century Skills and lessons learned by students are (a) creativity and innovation, (b) critical thinking and problem solving, (c) communication skills and (d) cooperative skills (Piirto, 2011).

The standard competencies of physics in high school require students to do experiment such as formulating problems, proposing and testing hypotheses, defining variables, designing and compiling instruments, collecting, processing and interpreting data, drawing conclusions, and communicating the results of experiments in oral and written forms. To meet these competencies, teachers are asked to facilitate, motivate, direct, and guide students in practical activities and discoveries (Bahtiar, Rahayu, and Wasis, 2018).

Some learning models are developed by placing students as the center of learning in the classroom. The learning model applied in the cottage is one of the learning models that can be developed in physics learning. The model of learning is applied in the boarding school of Tahfidz Yanbu'ul Qur'an Menawan (PTYQM) Kudus. The boarding school has a special model in tahfidz learning, foreign language habituation, and classical islamic text book review. Developing the learning model with the tools becomes very important to foster the ability of students in improving their imagination and creativity (Sumarmo, 2005). Most physics students cannot use what is learned in the classroom to solve problems in new situations (Watkins and Mazur, 2013). The results of this development are applied in 
physics learning material momentum and impulse to foster student problem solving abilities.

Some research related to boarding school education has been done a lot. The research conducted by Rinaningsih et al. (2016) on the application of pesantren pondok method concluded that Sorogan and Bandongan method in Organic Chemistry learning can be effectively used in the development of learning model. In addition, Asnawan (2016) stated that traditional education system that is implemented correctly in boarding school Assunniyyah, Kencong, Jember is able to produce many alumnae into people who can empower the surrounding such as caretaker of boarding school, scholars, and so forth. Schools based on boarding schools play a significant role in the nation character building efforts and have good problem solving skills. Kharida (2009) in classroom action research found increase in terms of the average of cognitive learning outcomes by 0.26 or $26 \%$ through the problem-based learning model.

\section{Methods}

This research includes the type of development research using Thiagarajan and Semmel modeled by modified 4-D model (define, design, develop, disseminate). The subjects of the study were X-MIA students of MAS Tahfidz Yanbu'ul Qur'an Kab. Kudus as many as 38 students. Design of the research used is a group of pretest-posttest or Research Design of One-Group Pretest-Posttest (Sugiyono, 2010).

Data were obtained from various data collection techniques such as observation and test sheets. The observation sheet was used to find out the application level of the strategy learning model used in the class. This observation was related to the activities of teachers and students in learning. The test was used to analyze and validate students' problemsolving abilities. This test had been validated by an education expert before being used in the class then analyzed to obtain validity and improvement. (Saragih, Elvis, and Amin, 2017).

The test instrument used in this research was a written test in the form of structured description to measure the ability of problem solving physics. The problem solving test was presented in essay form calculated based on four criteria which consisted of (1) description of data and information, (2) description of problem to be solved, (3) implement solution (solution accuracy), and (4) evaluation of solution accuracy of results).

The criterion of physics problem solving ability about momentum and impulse through the typical cottage learning model was categorized according to the result of gain obtained from the average student score according to Sundayana (2014), and it can be seen in Table 1.

Table 1. Normalized Gain Index Criteria

\begin{tabular}{cc}
\hline Gained criterion $\langle\mathrm{g}>$ & Interpretation \\
\hline $0.70 \leq \mathrm{g}>1.00$ & High \\
$0.30 \leq<\mathrm{g}>\leq 0.70$ & Medium \\
$0.00<\mathrm{g}<0.30$ & Low \\
$\mathrm{g}=0.00$ & No increase \\
$-1.00 \leq \mathrm{g}<0.00$ & There was a decline \\
\hline
\end{tabular}

\section{Result and Discussion}

The development of cottage based learning model followed four steps as follows.

\subsection{Defining}

Physics learning model that was developed based on the learning model applied in PTYQM Kudus deals with classical islamic text book review, tahfidz learning, and foreign language habituation.

\section{a. Islamic Text Book Review}

A deep religious understanding can be gained by studying the books of previous Teachers Religions (Ulema). Those book are usually written in Arabic and written without signs (harokat). To study this book, it is required special strategies and methods. The methods applied were sorogan, bandungan, and taqror.

This method of reading islamic text books led the students to study independently after getting an explanation or examples from the teachers. A student had to dare to try to work independently to hone his own ability. If there was a mistake then the teachers' role is to justify.

This method of learning is in accordance with the theory of constructivism. Constructivism emphasizes the importance of knowledge, beliefs, and skills brought by a person into the learning experience (Garbett, 2011). Constructivism as a learning theory 
assumes that learners play an active role in constructing meaning by themselves (Conru and Peters, 2005). Learning is an active process, and knowledge is built on the experience and personal interpretation of the world. Constructivism benefits students in many ways as Christie asserts that it helps students pursue personal interests and goals through using and developing learners' abilities as well as built on the learners' previous knowledge and experience and developing lifelong learning.

\section{b. Tahfidz Learning}

Learning tahfidz (memorizing Al-quran) is a leading local content curriculum. The method used in learning tahfidz was called halaqoh or small group. The students were divided into groups of 8-9 in each halaqoh held by a teacher. Master listened to the recitation and santri read one by one. If there was a mistake in memorization and eloquence, then the teacher reminded the students. At the end of each lesson, the teacher wrote the achievement of the learning result on the student achievement books.

The activity applied was discussion activity. Powell and Kalina (2009) stated that collaboration and social interaction are included in social constructivism. Creating a deeper understanding of learning requires cooperative learning. Another form of activity of cooperative learning is practicum activity. Educational technological tools can take the concept of science that is difficult to learn and turn it from abstract to concrete to make it easier to understand (Alias and Saedah, 2012).

The development of this method was that students needed to be explored by the teachers directly. Assessing the ability of students directly by facing the teacher made the students more responsible in doing the task and dare to ask if there was a problem. This assessment also enhanced emotional attachment between students and teachers. Through this method students were directed to be creative, have hard-working, self-reliant, honest, disciplined, good in social attitudes, confident, as well as develop an open and objective attitude of the mind needed in facing the future. Through this method students connected any new information with prior knowledge either individually or when interacting with colleagues or teachers (Aina, 2017).

\section{c. Foreign Language Habituation}

Foreign languages used in PTYQM were Arabic and English. The application of this foreign language required special methods in order to run maximally. The methods used were routine vocabulary involving students to the languages in daily activities and monitoring the use of foreign language.

Foreign language habituation model could be developed by giving basic formula related to the taught material that was about momentum and impulse. Students also needed to be invited to apply the material learned in real life. Another development was to invite students to be able to assess colleagues. This learning made students learn with their minds and at the same time interact with the environment when learning took place. Through this method the students' characters became active and able to interact with the environment either themselves or with others (Packer and Goicoechea, 2000).

\subsection{Designing}

The syntax design of cottage-based learning model development is presented as follows.

Step 1: Student's orientation on the problem Master's Behavior

- Teacher explains the purpose of learning.

- The teacher delivers the introductory material.

- Teacher relates matter to problems in everyday life.

- $\quad$ Teacher directs learners to ask questions.

Student Behavior

- Learners pay attention to what the teacher is saying.

- Learners respond to problems presented by the teacher.

- Learners ask related material submitted.

Step 2: Organizing independent learning in groups

Master's Behavior

- Teacher divides learners into groups.

- Teacher distributes the discussion/ practicum sheet.

- Teacher observes the performance of learners.

Student Behavior

- Learners are grouped according to the division.

- Learners work on the discussion sheet independently. 


\section{Step 3: Organizing learning group}

Master's Behavior

- Teacher directs learners to continue learning activities on group discussion/ lab activities.

- Teacher observes and assesses learners' performance.

Student Behavior

- Learners deliver their own work to their group members

- Learners discuss problems as a group.

Step 4: Independent and group investigations

Master's Behavior

- Teacher calls representatives of group members to present the outcome of discussions while the other groups can ask questions.

Student Behavior

- The appointed student advances to the teacher to present the results of the group's discussions or ask questions.

\section{Step 5: Problem solving analysis}

Master's Behavior

- Teacher observes and assesses learners' performance.

- Teacher guides learners in group activities.

Student Behavior

- Learners return into the group to analyze more deeply to the problems given and solve them.

Step 6: Presenting the results of the discussion and communicate

Master's Behavior

- The teacher directs the learners to collect the results of the discussion / practicum.

- Teacher designates one group to present the result of the discussion / lab.

- $\quad$ Teacher guides presentation activities

Student Behavior

- Learners collect their own work and group discussions.

- Group representatives present the results of discussion / lab work.

- Other group members respond to advanced group presentations and vice versa.

Step 7: Summarizing the material as intended

Master's Behavior

- Teacher confirms learning outcomes and directs according to stated goals

\section{Student Behavior}

- Learners pay attention to teachers about learning outcomes.

- Learners record learning outcomes.

\section{Step 8: Material development}

Master's Behavior

- Teacher gives a material summary.

- Teacher appoints some learners to assess their peers.

Student Behavior

- Learners record material summaries.

- $\quad$ Teacher designates learners to assess their peers.

\subsection{Developing}

The results of this model development were validated by three expert teams: experts in physics, education, and boarding school. The validation got an average value of 87.83 with good criteria, and it could be applied in learning with a few revisions.

\subsection{Disseminating}

The result of cottage model development was applied in physics learning dealing with momentum and impulse. The learning led to an assessment of students' problem-solving abilities. The final assessment results showed that the average value of problem solving ability of students reached 74 . Classical completeness based on the completeness criteria was at least $81.56 \%$. The magnitude of the physics problem-solving abilities of momentum and impulses from the last daily and post-test value data were calculated using the normalized gain in the 0.62 assessment criteria with moderate interpretation.

\section{Conclusion}

The development of cottage learning model can be used as an alternative model of physics learning. The development of this model is applied in accordance with existing learning theories. Application of cottage model development can help students have high physics problem solving skills as well as student character building.

\section{References}

Anwar, Ali. (2008). Pembaharuan Pendidikan di Pesantren Lirboyo, Kediri: IAIT Press.

Shafwan, M. H. (2014). Intisari Sejarah Pendidikan Islam Solo: Pustaka Arafah. 
Rahardjo, Mudjia, Ed. (2006). Quo Vadis Pendidikan Islam: Membaca Realitas Pendidikan Islam, Sosial dan Keagamaan. Malang: UIN-Malang Press. Alismail, H.A., McGirne, P. (2015). 21 ${ }^{\text {st }}$ Century Standard and Curriculum: Current Research and Practice. Journal of Education and Practice. 6(6).

Piirto, J. (2011). Creativity for $21^{\text {st }}$ Century Skills, How to Embed Creativity into the Curriculum. Rotterdam: Sense Publishers.

Bahtiar, Y. S., Rahayu, Wasis,. (2018). Developing Learning Model P3E to Improve Students' Critical Thinking Skills of Islamic Senior High School. Journal of Physics. 967.

Sumarmo, U. (2005). Pengembangan Berfikir Matematik Tingkat Tinggi Siswa SLTP dan SMU serta Mahasiswa Strata Satu (S1) melalui Berbagai Pendekatan Pembelajaran. Laporan Penelitian Lemlit. UPI: Unpublished.

Watkins, J., \& Mazur, E. (2013). Retaining Students In Science, Technology, Engineering, And Mathematics (STEM) Majors. Journal of College Science Teaching 42(5).

Rinaningsih, A. Kadarohman, H. Firman, and Suyatno. (2016). Penerapan Metode Pembelajaran Pondok Pesantren Dalam Perkuliahan Kimia Organik Materi Mekanisme Reaksi Sn1 Dan Sn2. Prosiding Seminar Nasional Kimia dan Pembelajarannya, Jurusan Kimia FMIPA Universitas Negeri Surabaya.

Asnawan. (2016). Integrasi Pendidikan Formal Dan Pendidikan Diniyah Salafiyah Terhadap Santri Assunniyyah Kencong Jember Sebagai Antisipasi Ouput Pesantren Di Era Regulasi Pendidikan Nasional 2016. Falasifa. 7(1).

Kharida, L. A., A. Rusilowati, and K. Pratiknyo. (2009). Penerapan Model Pembelajaran Berbasis Masalah Untuk
Peningkatan Hasil Belajar Siswa Pada Pokok Bahasan Elastisitas Bahan. Jurnal Pendidikan Fisika Indonesia 5.

Sugiyono. (2010). Metode Penelitian Kuantitatif, Kualitatif, dan $R \& D$. Bandung : CV. Alfabeta

Saragih, S., Elvis, N., and Amin, F. (2017) Developing Learning Model Based on Local Culture and Instrument for Mathematical Higher Order Thinking Ability. International Education Studies $10(6)$.

Sundayana, Rostina. 2014. Statistika Penelitian Pendidikan. Bandung: Alfabeta

Garbett, D. (2011). Constructivism Deconstructed in Science Teacher Education. Australian Journal of Teacher Education. 36(6).

Cornu, R.L., \& Peters, J. (2005). Towards constructivist classrooms: the role of the reflective Teacher. Journal of Educational Enquiry, 6(1).

Powell, K.C., ED.D., \& Kailna, C. J. (2009). Cognitive and social constructivism: Developing tools for an effective classroom. Education. 130(2).

Alias, N. and Saedah, S. (2012). Design and Development of Physics Module Based on Learning Style And Appropriate Technology By Employing Isman Instructional Design Model. The Turkish Online Journal of Educational Technology. (11)4.

Aina, Jacob, K. (2017). Developing a Constructivist Model for Effective Physics Learning International Journal of Trend in Scientific Research and Development (1)4.

Packer, M., \& Goicoechea, J,. (2000). Sociocultural and Constructivist Theories of Learning: Ontology, Not Just Epistemology. Educational Psychologist (3) 5 . 